\title{
Application Status of Dry Desulfurization in Industrial Waste Gas Treatment
}

\author{
Hong-Mei LIU ${ }^{\mathrm{a}}$, Huan-Huan LI ${ }^{\mathrm{b},}$, Yao YAO ${ }^{\mathrm{c}}$, Jian-Jun WANG ${ }^{\mathrm{d}}$ and Le MI \\ Nantong University main campus School of Mechanical Engineering, Seyuan Road on the 9th \\ Chongchuan District Nantong City, Jiangsu Province, China

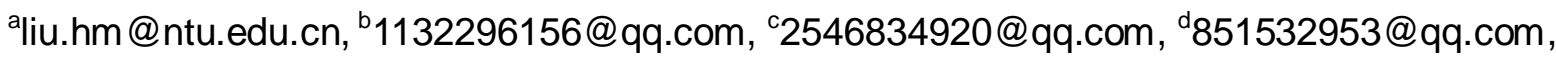 \\ e1650055720@qq.com \\ ${ }^{*}$ Corresponding author
}

Keywords: Industrial Waste Gas, Pollution Control, Dry Desulfurization.

\begin{abstract}
In recent years, with the deepening of the green development concept and the increasingly stringent environmental regulations, how to deal with the problem of industrial waste gas has become a major challenge for industrial enterprises. This paper mainly expounds the harm of industrial waste gas, as well as the main methods of dry desulfurization. And the principle and advantages and disadvantages were analyzed. The development trend of dry desulfurization is prospected at the end.
\end{abstract}

\section{Introduction}

With the rapid social and economic development, industrial technology has been steadily progressing, which brings a very serious air pollution. In recent years, a large number of areas in China have a wide range of haze weather, which caused the government and people's attention. At present, the treatment of sulfide in industrial waste gas can be divided into three categories: dry cleaning, wet cleaning and semi-dry purification. This paper describes the dry desulfurization in details.

\section{Hazard of Sulfide in Industrial Waste Gas}

At present, China's industrial production mainly based on fossil fuels. In the production process, the combustion of fossil fuels will produce a lot of harmful gases, which not only pollute the ecological environment, but also pose a huge threat to human health. The most serious is the sulfide, and the main hazards as following aspects: (1)Stimulate the human respiratory tract and other mucosal tissues, causing physiological dysfunction. (2)Damage the plant wax surface of the waxy protective layer, so that the leaves fall off, resulting in decreased plant yield and quality degradation. (3) The formation of acid rain will corrode the building and contaminate the groundwater and so on. Thus, in order to make air pollution issues are effectively resolved, while carries out industrial upgrading, industrial exhaust gas purification work is also very important.

\section{Principles of Dry Desulfurization}

The basic principle of dry desulfurization is to let the gas through the solid adsorption layer, using powder absorbent, catalyst and other materials to absorb the gas. Compared with other purification methods, dry cleaning has many advantages. It has the advantages of simple process, no waste water, dry working environment, little corrosion to the exhaust pipe, and can prolong the service life of the pipeline. There is no need to carry out the second heating, which is beneficial to discharge because of high flue gas temperature after dry desulfurization.

\section{Dry Desulfurization Process}

\section{Rotating Spray Drying}

Rotary spray drying system is mainly composed of absorption tower, dust removal equipment, 
atomizer and feed, slurry preparation system and drying conveying system. The principle of spray drying is mainly used in desulfurization. When the absorber enters the absorption tower, it will react with the sulfur dioxide in the absorption tower to produce sulfate. At the same time, the waste heat constantly drying absorbent, which can reduce the cost of purification. In the absorption tower, the waste produced after purification is solid dust, part of the ash into the library, and the other part company with purified gas into the dust collector. The main chemical reactions are as follows:

Lime pulping:

$$
\mathrm{CaO}+\mathrm{H}_{2} \mathrm{O}=\mathrm{Ca}(\mathrm{OH})_{2}
$$

Sulfur dioxide absorbed by droplets:

$$
\mathrm{SO}_{2}+\mathrm{H}_{2} \mathrm{O}=\mathrm{H}_{2} \mathrm{SO}_{3}
$$

Reaction of absorbent with sulfur dioxide:

$$
\mathrm{Ca}(\mathrm{OH})_{2}+\mathrm{H}_{2} \mathrm{SO}_{3}=\mathrm{CaSO}_{3} \downarrow+2 \mathrm{H}_{2} \mathrm{O}
$$

The rotary spray drying method is a relatively mature process, which has the advantages of high efficiency of removing sulfur, no waste water, purification products, easy to recycle, low investment and operating costs and low production costs. The most important factor affecting the efficiency of removing sulfur is the ratio of calcium to sulfur. When the ratio of calcium to sulfur is controlled in the appropriate range, the efficiency of removing sulfur is more efficient and stable, the general calcium to sulfur ratio of $1.3 \sim 1.5$.

\section{Electron Beam Irradiation Desulfurization}

Electron beam flue gas desulfurization is a new technology that combines physical and chemical methods. At present, the composition of industrial waste gas is mainly composed of nitrogen, oxygen, water vapor, $\mathrm{CO}_{2}$ and other harmful components such as $\mathrm{SO}_{2}, \mathrm{NOx}$ and so on. When the exhaust gas from the industry enters the reactor, the electron beam is irradiated, and $\mathrm{N}, \mathrm{O}$ and $\mathrm{HO}_{2}$ in the flue gas absorb the electron beam energy to generate reactive radicals such as $\mathrm{OH}$ groups, $\mathrm{O}$ groups, $\mathrm{HO}_{2}$ groups and $\mathrm{N}$ groups, The free radicals react with $\mathrm{SO}_{2}$ and $\mathrm{NOx}$ in the flue gas to produce sulfuric acid $\left(\mathrm{H}_{2} \mathrm{SO}_{4}\right)$ and nitric acid $\left(\mathrm{HNO}_{3}\right)$ [2]. When the electron beam is irradiated, ammonia $\left(\mathrm{NH}_{3}\right)$ is introduced into the reactor, and the ammonia is neutralized with sulfuric acid and nitric acid to produce ammonium salt:

$$
\begin{aligned}
& \mathrm{H}_{2} \mathrm{SO}_{4}+2 \mathrm{NH}_{3}=\left(\mathrm{NH}_{4}\right)_{2} \mathrm{SO}_{4} \\
& \mathrm{HNO}_{3}+\mathrm{NH}_{3}=\mathrm{NH}_{4} \mathrm{NO}_{3} \\
& 2 \mathrm{SO}_{2}+\mathrm{O}_{2}+4 \mathrm{NH}_{3}+2 \mathrm{H}_{2} \mathrm{O}+\mathrm{SO}_{3}=2\left(\mathrm{NH}_{4}\right) 2 \mathrm{SO}_{4}
\end{aligned}
$$

The electron beam has the characteristics of strong penetration and high energy, so the time of purification reaction is very short, the efficiency of purification is high, and the by-product after purification can also be used as agricultural nitrogen fertilizer with great economic benefits. However, before the flue gas enters the reactor, it is necessary to carry out cooling treatment, which requires the re purification of the flue gas system to reheat system to ensure that the flue gas emissions.

\section{Solid Phase Adsorption Desulfurization}

This technology uses solid absorbent or catalyst to absorb sulfur dioxide by physical or chemical methods. At present, the adsorption method is activated carbon and $\mathrm{CuO} / \mathrm{Al}_{2} \mathrm{O}_{3}$ absorption method. Activated carbon activated carbon to absorb $\mathrm{SO}_{2}$. When there is no water vapor in the flue gas, the adsorption of $\mathrm{SO}_{2}$ on activated carbon will be physical adsorption; When water and oxygen are 
present, both physical and chemical reactions are present. These reactions produce sulfuric acid and other products, sulfur removal efficiency is improved. The products produced by the adsorption of $\mathrm{SO}_{2}$ on activated carbon remain in the pores of activated carbon, which can be recycled or reused by means of cleaning or heating.

The products produced by the adsorption of $\mathrm{SO}_{2}$ on activated carbon remain in the pores of activated carbon, which can be recycled or reused by means of cleaning or heating. When the adsorbent absorbs saturation, $\mathrm{CuSO}_{4}$ reacts with $\mathrm{H}_{2}$ or $\mathrm{CH}_{4}$ in the regenerator to release $\mathrm{SO}_{2}$. At this point, the release of $\mathrm{SO}_{2}$ through the recovery device for acid recovery; reduction of the $\mathrm{Cu}$ in the flue gas can be oxidized into $\mathrm{CuO}$, it can be re-participate in the desulfurization process [3].

Compared with the $\mathrm{CuO} / \mathrm{Al}_{2} \mathrm{O}_{3}$ absorption method, the activated carbon adsorption method does not have second pollution, and there is no system corrosion. It can also remove $\mathrm{SO}_{2}$, dioxins, volatile organic compounds and other harmful substances. However, this method has the disadvantages of large consumption of activated carbon, high operation cost and low absorption efficiency of low concentration waste gas. The absorption efficiency of $\mathrm{CuO} / \mathrm{Al}_{2} \mathrm{O}_{3}$ absorption method is relatively high, but there are some problems such as ammonia leakage.

\section{Circulating Fuidized Bed Desulfurization}

Circulating fluidized bed desulfurization system is mainly composed of lime slurry preparation system, desulfurization reaction tower and dust removal system. The desulfurizing agent is slaked lime powder and the fluidized bed is in the reaction tower. At work, industrial waste gas from the fluidized bed bottom into the fluidized bed, and desulfurization agent $\mathrm{Ca}(\mathrm{OH})_{2}$ is fully mixed, while the reaction tower spray, activation of desulfurization agent, reacting with $\mathrm{SO}_{2}$ acid gas, the main products are $\mathrm{CaSO}_{3}$ and $\mathrm{CaSO}_{4}[4]$. The main reactions occurring in the fluidized bed include:

$$
\begin{aligned}
& \mathrm{SO}_{2}+\mathrm{Ca}(\mathrm{OH})_{2}=\mathrm{CaSO}_{3} \downarrow+\mathrm{H}_{2} \mathrm{O} \\
& \mathrm{Ca}(\mathrm{OH})_{2}+\mathrm{SO} 3=\mathrm{CaSO}_{4}+\mathrm{H}_{2} \mathrm{O} \\
& \mathrm{Ca}(\mathrm{OH})_{2}+2 \mathrm{HCl}=\mathrm{CaCl}_{2}+2 \mathrm{H}_{2} \mathrm{O} \\
& 2 \mathrm{Ca}(\mathrm{OH})_{2}+2 \mathrm{SO}_{2}+\mathrm{O}_{2}=2 \mathrm{CaSO}_{4}+2 \mathrm{H}_{2} \mathrm{O} \\
& \mathrm{Ca}(\mathrm{OH})_{2}+2 \mathrm{HF}=\mathrm{CaF}_{2}+2 \mathrm{H}_{2} \mathrm{O}
\end{aligned}
$$

The circulating fluidized bed desulfurization process is mainly divided into NID (Lurgi) type circulating fluidized bed desulfurization, reflux fluidized bed desulfurization, gas suspension absorption desulfurization (GSA) and NID desulfurization. The main factors affecting the desulfurization efficiency of this method are the ratio of calcium to sulfur in the fluidized bed, the concentration of the bed material, the circulating rate and the temperature of the reaction tower. In the process of operation, the bed temperature can be controlled under the optimum reaction temperature, so as to achieve the best condition of the turbulent mixing between gas and solid. In this case, the reaction of $\mathrm{Ca}(\mathrm{OH})_{2}$ can be produced continuously. At the same time increasing the number of circulating fluidized bed, so that the retention time of the desulfurization agent longer, it can improve the desulfurization efficiency of desulfurization agent.

\section{Charged Dry Sorbent Injection Desulfurization Method}

The charging system is composed of absorbent injection unit, absorbent feed system and sulfur dioxide control detection system. Absorbent $\mathrm{Ca}(\mathrm{OH})_{2}$ passes through the jet unit at high speed with its surface attached to a strong negative charge. A high voltage electrostatic corona zone is generated by the injection unit. The mutual repulsion between each other is carried out because the absorbent carries negative charge, so as to disperse rapidly in the flue gas and fully react with $\mathrm{SO}_{2}$, the desulfurization efficiency is greatly increased[5]. In addition, the absorber surface with charge, can absorb the dust particles, but also can improve the efficiency of pollutants. The main reaction 
occurred in the process of sulfur removal:

$$
\mathrm{SO}_{2}+\mathrm{Ca}(\mathrm{OH})_{2}=\mathrm{CaSO}_{3} \downarrow+\mathrm{H}_{2} \mathrm{O}
$$

In addition, flue gas contains $\mathrm{H} 2 \mathrm{O}$ and $\mathrm{O} 2$, but also the following reactions:

$$
2 \mathrm{Ca}(\mathrm{OH})_{2}+2 \mathrm{SO}_{2}+\mathrm{O}_{2}=2 \mathrm{CaSO}_{4}+2 \mathrm{H}_{2} \mathrm{O}
$$

Compared with other methods, the dust removal efficiency is much higher than the traditional electrostatic dust removal technology. In addition, the method has no radiation and electron accelerator. The device has the advantages of simple equipment, high degree of automation, low installation and operation cost, and is suitable for low profit Industrial Enterprises. In recent years, many industrial enterprises, research and experiment of this method for scientific research personnel, such as the industrialization of flue gas desulfurization done by Chinese Wu Yan of the Dalian University of Technology in the using PPCP method, the desulfurization efficiency of this is up to $84 \%[6]$.

\section{Prospect}

Compared with wet desulfurization and semi dry desulfurization, dry method of sulfur removal does not produce waste residue. But this method is not researched enough in-depth with high production rate. Therefore, it is necessary to increase the research of dry desulfurization, so as to make it play its due role in the future industrial waste gas treatment.

\section{Reference}

[1] Ling WANG. Study on atmospheric environmental pollutants monitoring[J].Science and technology innovation and application, 2017(2): 178-178.

[2] Feng LI. Technology of flue Gas Desulfurizati on and Denitrification by lradiati on of electron Beam[J]. Environmental Protection Science, 2004, 30(3):4-6.

[3] Lin WANG, Song YANG, Yan Zi. Integrated technology for simultaneous desulfurization and denitrification of solid phase absorption / regeneration[J]. ceramics, 2016(11):23-24.

[4] Ya-Jing ZHAO. Application of circulating fluidized bed in flue gas desulfurization [J]. Journal of chemical engineering design, 2016, 42 (7): 11-11.

[5] De-Fang CHEN, Sa SA. The money charged dry sorbent injection desulfurization system [J]. energy research and information, 1999 (1): 18-27.

[6] Ya-Jing LU, Xiong source, D, et al. Experimental study on urea / triethanolamine wet flue gas desulfurization and denitrification of [J]. China ofthecsee, 2008, 28 (5): 44-50. 